\title{
International Volunteer Programs for Dental Students: Results of 2009 and 2016 Surveys of U.S. Dental Schools
}

\author{
Karl F. Woodmansey, DDS, MA; Briana Rowland, MBA; Steve Horne, MBA; \\ Francis G. Serio, DMD, MS, MBA
}

Abstract: The aims of this study were to determine the prevalence and nature of international volunteer programs for predoctoral students at U.S. dental schools and to document the change over five years. Web-based surveys were conducted in 2009 and 2016. An invitation to participate in the study, along with a hyperlink to the survey, was emailed to the deans of all U.S. dental schools in the two years. In 2009, 47 of 58 dental school deans responded to the survey, for a response rate of $81 \%$. In 2016,48 of 64 dental school deans responded, for a response rate of 75\%. From 2009 to 2016, the number of schools reporting dental student international experiences increased from 25 to 31 . In 2016, 65\% of responding schools offered dental student international experiences, an $11.5 \%$ increase over the results of the 2009 survey. Concomitantly, the number of deans reporting their students' participation in international opportunities not officially sanctioned by the school decreased from 41 to 34 . These findings showed an increase in the number of dental schools providing international experiences for their students and established baseline data to assess trends in the future.

\begin{abstract}
Dr. Woodmansey is Associate Professor and Director, Graduate Endodontics, Center for Advanced Dental Education, Saint Louis University and a Lieutenant Colonel in the Illinois Air National Guard assigned to the 126th Air Refueling Wing at Scott Air Force Base; Ms. Rowland is Manager of International Development and Outreach, ADA Foundation; Mr. Horne is Senior Manager of Marketing Research, American Dental Association; and Dr. Serio is Adjunct Professor, East Carolina University School of Dental Medicine and University of North Carolina-Chapel Hill School of Dentistry and a staff dentist at Greene County Health Care, Inc. Direct correspondence to Dr. Karl Woodmansey, Center for Advanced Dental Education, Room 1075, Saint Louis University, St. Louis, MO 63104; 314-977-8623; woodmanseykf@slu.edu.
\end{abstract}

Keywords: dental education, international programs, clinical education, cultural competence, community health education, world health

Submitted for publication 6/15/16; accepted 7/21/16

A s U.S. dental schools seek to provide their students with opportunities to experience dental education and dental practice beyond the walls of the traditional dental school, these experiences via externships, satellite clinics, and extramural rotations are designed to add to students' appreciation of real-world dentistry. However, the definition of "community" in community-based learning is expanding globally to offer dental students opportunities for international experiences in community/ clinical dentistry. ${ }^{1}$

The goals of these programs are varied, but typically include clinical dental education, enhancing students' cultural competence, promoting a lifelong spirit of volunteerism and humanitarianism, improving overall awareness of global health (including oral health), and illustrating global disparities in dental needs, education, and treatment resources. ${ }^{1-7}$ The reasons that students participate in these programs have been found to be just as varied..$^{8-15}$ The Harvard School of Dental Medicine estimated that nearly $25 \%$ of its predoctoral students had expressed interest in global health, including traveling abroad to conduct research or to volunteer in a project. ${ }^{7}$

We have observed that the international dental volunteer programs offered by U.S. dental schools vary widely in structure and scope. Some are formalized long-standing relationships with international sister institutions, while others are ad hoc spring break vacations blended with dental service. Some programs offer students credit for procedures performed at these international locations, while others are less academic. Some programs are authorized by a school but coordinated by external organizations, such as nonprofit humanitarian aid organizations or religious groups that organize mission trips.

We have also seen that individual schools apply a wide variety of terms to describe dental student international programs: humanitarian, volunteer, mission, externship, opportunity, outreach, and service-learning, among other terms. These programs should not be confused with those offered by U.S. dental schools for the purposes of educating dentists from abroad for U.S. licensure although 
both of these types of programs may be referred to as "international programs." Our study focused only on programs that send dental students from U.S. dental schools to international locations, predominantly in underserved areas, for clinical dentistry experiences, which we will call dental student international experience programs (DSIEP).

In 1971, Farrell published the earliest study of DSIEP at U.S. dental schools. ${ }^{16}$ Her review was an informal compilation of known DSIEP at that time. Since 1971, dental education has expanded greatly, and DSIEP have evolved too. With no contemporary inventory of DSIEP at U.S dental schools, the aims of this study were to determine the prevalence and nature of international volunteer programs for predoctoral students at U.S. dental schools and to document their change over five years. Surveys were conducted in 2009 and 2016 for these purposes.

\section{Materials and Methods}

In 2009, we developed a survey to support the aims of the study. With the support and approval of the American Dental Association (ADA) International Development Subcommittee, a hyperlink to the web-based survey (FluidSurveys, SurveyMonkey Canada, Ottawa, ON, Canada) was distributed to the deans of the 58 U.S. dental schools on March 26, 2009. Four follow-up mailings were intermittently sent by email to all nonrespondents. Data collection for that survey ceased on July 16, 2009.

In 2016, a nearly identical survey was approved and supported by the ADA Foundation's International Programs Subcommittee. Using identical methodology, a hyperlink to the web-based survey was distributed to the deans of the 64 U.S. dental schools on January 21, 2016. Data collection for that survey ceased on February 19, 2016. For both surveys, all respondents were volunteers, with no compensation offered. The data were reported anonymously and analyzed using basic descriptive statistics and comparisons.

\section{Results}

In 2009, representatives of 47 of 58 dental schools responded to the survey, for a response rate of $81 \%$. In 2016, representatives of 48 of 64 dental schools responded to the survey, for a response rate of $75 \%$. In that interval from 2009 to 2016, the number of schools with DSIEP increased from 25 to 31 . In the 2009 survey, $53 \%$ of the responding schools offered DSIEP. In 2016, 64.5\% of the responding schools offered DSIEP. The 2016 results represent an $11.5 \%$ increase in responding schools' DSIEP participation over the 2009 results. The findings are summarized in Table 1, Table 2, Table 3, Table 4, and Table 5.

Although the number of schools with reported DSIEP increased for this five-year period, the number of schools in which dental students participated in international opportunities without school sanctions decreased from 41 to 34 . However, the number of schools who partnered with outside organizations increased from 17 to 22 . Most surprisingly, the number of schools offering educational credits for DSIEP participation decreased from 15 to seven. The number of schools with reciprocal programs with partner countries increased from five to eight.

\section{Discussion}

Members of prior generations may have learned of other cultures from such sources as the pages of

Table 1. Features of international programs at U.S. dental schools, by number and percentage of respondents to each item

\begin{tabular}{|c|c|c|c|c|}
\hline \multirow[b]{2}{*}{ Feature } & \multicolumn{2}{|c|}{2009} & \multicolumn{2}{|c|}{2016} \\
\hline & Number $(\%)$ & Total N & Number (\%) & Total N \\
\hline School offers international volunteer programs. & $25(56 \%)$ & 47 & $31(65 \%)$ & 48 \\
\hline Dental students participate in international opportunities not offered by school. & $41(87 \%)$ & 47 & $34(71 \%)$ & 48 \\
\hline Programs are offered during academic year and vacation. & $30(64 \%)$ & 47 & $16(33 \%)$ & 48 \\
\hline Programs are offered during vacation/break time only. & $15(32 \%)$ & 47 & $13(27 \%)$ & 48 \\
\hline Programs are managed by faculty or dental school administrator. & $38(81 \%)$ & 47 & $27(90 \%)$ & 30 \\
\hline Programs have 0-40 student participants each year. & $18(72 \%)$ & 25 & $23(88 \%)$ & 26 \\
\hline Trips are funded by the student/participant. & $21(84 \%)$ & 25 & $23(88 \%)$ & 26 \\
\hline School has reciprocal program with partner countries. & $5(20 \%)$ & 25 & $8(33 \%)$ & 24 \\
\hline
\end{tabular}


Table 2. Responses to questions about dental schools' international programs, by number and percentage of yes/no responses to each question

\begin{tabular}{|c|c|c|c|c|c|c|}
\hline \multirow{2}{*}{ Question } & \multicolumn{3}{|c|}{2009} & \multicolumn{3}{|c|}{2016} \\
\hline & $\begin{array}{l}\text { Yes } \\
(\%)\end{array}$ & $\begin{array}{l}\text { No } \\
(\%)\end{array}$ & $\begin{array}{c}\text { Total } \\
\mathrm{N}\end{array}$ & $\begin{array}{l}\text { Yes } \\
(\%)\end{array}$ & $\begin{array}{l}\text { No } \\
(\%)\end{array}$ & $\begin{array}{c}\text { Total } \\
\mathrm{N}\end{array}$ \\
\hline $\begin{array}{l}\text { Are dental students offered educational/clinical credits for participation } \\
\text { after volunteering? }\end{array}$ & $\begin{array}{c}15 \\
(60 \%)\end{array}$ & $\begin{array}{c}10 \\
(40 \%)\end{array}$ & 25 & $\begin{array}{c}7 \\
(27 \%)\end{array}$ & $\begin{array}{c}19 \\
(73 \%)\end{array}$ & 26 \\
\hline $\begin{array}{l}\text { Are students in your school's volunteer programs supervised on-site in } \\
\text { the foreign countries by a faculty member? }\end{array}$ & $\begin{array}{l}23 \\
(92 \%)\end{array}$ & $\begin{array}{c}2 \\
(8 \%)\end{array}$ & 25 & $\begin{array}{l}25 \\
(96 \%)\end{array}$ & $\begin{array}{c}1 \\
(4 \%)\end{array}$ & 26 \\
\hline $\begin{array}{l}\text { Is there a language requirement for students to participate in any of your } \\
\text { school's volunteer trips? }\end{array}$ & 0 & $\begin{array}{l}25 \\
(100 \%)\end{array}$ & 25 & $\begin{array}{l}24 \\
(92 \%)\end{array}$ & $\begin{array}{c}2 \\
(8 \%)\end{array}$ & 26 \\
\hline Are students provided accommodations on the volunteer trips? & $\begin{array}{c}20 \\
(80 \%)\end{array}$ & $\begin{array}{l}5 \\
(20 \%)\end{array}$ & 25 & $\begin{array}{c}23 \\
(88 \%)\end{array}$ & $\begin{array}{l}3 \\
(12 \%)\end{array}$ & 26 \\
\hline $\begin{array}{l}\text { Are there any combined courses taught simultaneously via the web or } \\
\text { distance learning programs between your school and the partner institution? }\end{array}$ & $\begin{array}{c}1 \\
(4 \%)\end{array}$ & $\begin{array}{l}23 \\
(96 \%)\end{array}$ & 24 & $\begin{array}{c}1 \\
(13 \%)\end{array}$ & $\begin{array}{c}7 \\
(87 \%)\end{array}$ & 8 \\
\hline $\begin{array}{l}\text { Are any of your international volunteer programs open to students from } \\
\text { other dental schools? }\end{array}$ & $\begin{array}{c}8 \\
(33 \%)\end{array}$ & $\begin{array}{c}16 \\
(67 \%)\end{array}$ & 24 & $\begin{array}{c}8 \\
(25 \%)\end{array}$ & $\begin{array}{l}24 \\
(75 \%)\end{array}$ & 32 \\
\hline $\begin{array}{l}\text { Does your school partner with other organizations or institutions to } \\
\text { manage the international volunteer programs? }\end{array}$ & $\begin{array}{c}17 \\
(71 \%)\end{array}$ & $\begin{array}{c}8 \\
(29 \%)\end{array}$ & 24 & $\begin{array}{l}22 \\
(67 \%)\end{array}$ & $\begin{array}{c}11 \\
(33 \%)\end{array}$ & 33 \\
\hline
\end{tabular}

the monthly National Geographic magazine. Today, however, globalization has "shrunk" the world, with other cultures shown daily on television and routine international travel providing first-hand intercultural experiences. The Internet offers unparalleled connectivity of students to all parts of the world via social and digital media. Furthermore, today's dental schools are culturally diverse, with students of many international backgrounds. Schools also now offer international programs for the purposes of educating dentists from abroad for U.S. dental licensure. These programs introduce an immediate multicultural blend into dental school environments. The diverse international mix of today's dental students may encourage both schools and students to embrace DSIEP.

We have observed that many of today's dental students have a history of service, volunteerism, and humanitarianism. Volunteerism now also appears in high school and college curricula. The benevolent spirit of this generation of dental students may encourage dental schools to provide service opportunities, including DSIEP, and to partner with other health professions schools in embracing international volunteerism - creating opportunities for interprofessional education.

In our study, the raw numbers of schools responding to the two surveys were similar: 47 in 2009 and 48 in 2016. However, because of the increased number of schools, the survey response rate actually decreased $6 \%$, from $81 \%$ to $75 \%$, between 2009 and 2016. However, the net effect reported by these surveys is that six more schools reported offering DSIEP in 2016 than in 2009. This change represents an $11.5 \%$ increase in responding schools' DSIEP participation during this interval. Although the number of schools with DSIEP increased from 25 to 31 between 2009 and 2016, the number of U.S. dental schools simultaneously increased during this interval: from 58 to 64 . This $10 \%$ increase in dental schools closely mirrors the $11.5 \%$ increase in responding schools' DSIEP participation.

Like most survey research, this study had several limitations. The individual respondents may have had biases that influenced both their decision to participate and their responses. Also, the results of these surveys must be interpreted cautiously because, despite repeated efforts inviting participation, not all dental schools responded, and not all surveys were completely answered. Consequently, although the response rates were satisfactory, the data sets are incomplete and may not be fully representative of the entirety of U.S. dental education. Because the nonresponding schools' DSIEP status remains unknown, the results reported here represent only the responding schools and not all U.S. dental schools.

In addition, these surveys represent only a partial view of dental student participation in international volunteer programs as some students may participate in non-school-affiliated trips. However, our study was based on the only known surveys of 
Table 3. Relationship between international programs and responding schools' curriculum goals

\begin{tabular}{lcccc} 
& \multicolumn{2}{c}{2009} & \multicolumn{2}{c}{2016} \\
\hline Relationship & Number & $\%$ & Number $\%$ \\
\hline Closely related & 11 & $44 \%$ & 12 & $36 \%$ \\
Somewhat related & 11 & $44 \%$ & 14 & $43 \%$ \\
Not related & 3 & $12 \%$ & 7 & $21 \%$ \\
Total & 25 & $100 \%$ & 33 & $100 \%$
\end{tabular}

Note: This question was worded as follows: Are the international dental volunteer programs related to the overall curriculum goals of the dental school?

Table 4. Number of international trips organized yearly at responding schools

\begin{tabular}{lcccc}
\multicolumn{2}{c}{2009} & \multicolumn{2}{c}{2016} \\
\hline Number & Number & $\%$ & Number $\%$ \\
\hline $1-2$ & 12 & $50 \%$ & 10 & $40 \%$ \\
$3-5$ & 7 & $29 \%$ & 8 & $32 \%$ \\
More than 5 & 5 & $21 \%$ & 7 & $28 \%$ \\
Total & 24 & $100 \%$ & 25 & $100 \%$
\end{tabular}

Note: This question was worded as follows: How many international volunteer trips are organized yearly by your school?

U.S dental schools on this topic. The data reported here include just two snapshots (2009 and 2016), which report a baseline against which future trends may be measured. With only two time points, whether any trend is developing is speculative until future data are collected.

\section{Conclusion}

Dental educators are challenged to help their students achieve clinical and cultural competence in a short period of time. DSIEP provide one possible means of achieving both goals. The results of our study may point to an emerging trend of an increasing number of dental schools providing DSIEP. Future studies may explore whether this trend endures and should better assess the reasons why dental schools participate in DSIEP. Additional research is also needed to better elucidate factors affecting the perceptions of both the students who participate in these ventures and their international patients, dental schools, and communities. Surveys should target dental students directly to assess their interest, participation, and educational outcomes related to
Table 5. Number of students in responding schools who participated in international trips

\begin{tabular}{lcccc} 
& \multicolumn{2}{c}{2009} & 2016 \\
\hline Number & Number & $\%$ & Number $\%$ \\
\hline Up to 20 & 11 & $44 \%$ & 12 & $46 \%$ \\
21 to 40 & 7 & $28 \%$ & 11 & $42 \%$ \\
41 to 60 & 4 & $16 \%$ & 1 & $4 \%$ \\
61 to 80 & 2 & $8 \%$ & 1 & $4 \%$ \\
81 to 100 & 0 & - & 1 & $4 \%$ \\
More than 100 & 1 & $4 \%$ & 0 & - \\
Total & 25 & $100 \%$ & 26 & $100 \%$
\end{tabular}

Note: This question was worded as follows: How many dental students participate in the offered international trips each year?

DSIEP. Other research could assess patient, institution, and community outcomes at the international locations to assess whether these programs result in mutually beneficial relationships.

\section{Acknowledgments}

The authors thank the American Dental Association (ADA)'s International Development Subcommittee, the ADA Foundation's International Programs Subcommittee, and the International College of Dentists for their support of this study.

\section{Disclosure}

The authors disclosed no financial, economic, or professional interests that may have influenced the design, execution, or presentation of this research.

\section{REFERENCES}

1. Seymour B, Barrow J. A historical and undergraduate context to inform interprofessional education for global health. J Law Med Ethics 2014;Winter:9-16.

2. Bimstein E, Gardner QW, Riley JL, Gibson RW. Educational, personal, and cultural attributes of dental students' humanitarian trips to Latin America. J Dent Educ 2008;72(12):1493-509.

3. Cohen LK, Valachovic RW. Students passionate for global health: dental schools beginning to respond. Compend Contin Educ Dent 2012;33(7):470-1.

4. Friedman A, Loh L, Evert J. Developing an ethical framework for short-term international dental and medical activities. J Am Coll Dent 2014;81(1):8-15.

5. Karim A, Mascarenhas AK, Dharamsi S. A global oral health course: isn't it time? J Dent Educ 2008;72(11): 1238-46.

6. Martinez-Mier EA, Soto-Rojas AE, Stelzner SM, et al. An international, multidisciplinary, service-learning program: an option in the dental school curriculum. Educ Health 2011;24(1):259. 
7. Seymour B, Benzian H, Kalenderian E. Voluntourism and global health: preparing dental students for responsible engagement in international programs. J Dent Educ 2013;77(10):1252-7.

8. Wynn LA, Krause DW, Kucine A, et al. Evolution of a humanitarian dental mission to Madagascar from 1999 to 2008. J Dent Educ 2010;74(3):289-96.

9. Blake A, March P, Miller C. Dental school volunteerism. J Am Coll Dent 2014;81(2):4-11.

10. Bohnert M. A student's perspective on the ethics of international charity dental care. J Am Coll Dent 2014; 81(1):28-30.

11. Crouch S, Farkash J, Branch A, et al. To Brazil and back: an international dental student exchange program. J Mich Dent Assoc 2015;97(7):40,42-3.
12. Hardwick KS. Volunteering for the long-term good. Compend Contin Educ Dent 2009;30(3):126-8.

13. Ivanoff CS, Ivanoff AE, Yaneva K, et al. Student perceptions about the mission of dental schools to advance global dentistry and philanthropy. J Dent Educ 2013;77(10):1258-69.

14. Thind A, Atchison K, Andersen R. What determines positive student perceptions of extramural clinical rotations? An analysis using 2003 ADEA senior survey data. J Dent Educ 2005;69(3):355-62.

15. Seymour B, Barrow J, Kalenderian E. Results from a new global oral health course: a case study at one dental school. J Dent Educ 2013;77(10):1245-51.

16. Farrell E. Foreign study: growth of continuing education and student programs. J Am Dent Assoc 1971;82(5): 969-72. 